University of Nebraska - Lincoln

DigitalCommons@University of Nebraska - Lincoln

Faculty Biographies and Links -- ADAPT

Program

ADAPT Program -- Accent on Developing Abstract Processes of Thought

Winter 1985

\title{
Developing Formal Reasoning through the Study of English
}

Anton E. Lawson

Arizona State University, anton.lawson@asu.edu

Elmer A. Kral

Grand Island Senior High School, Grand Island, Nebraska

Follow this and additional works at: https://digitalcommons.unl.edu/adaptfaculty

Part of the Curriculum and Instruction Commons

Lawson, Anton E. and Kral, Elmer A., "Developing Formal Reasoning through the Study of English" (1985). Faculty Biographies and Links -- ADAPT Program. 4.

https://digitalcommons.unl.edu/adaptfaculty/4

This Article is brought to you for free and open access by the ADAPT Program -- Accent on Developing Abstract Processes of Thought at DigitalCommons@University of Nebraska - Lincoln. It has been accepted for inclusion in Faculty Biographies and Links -- ADAPT Program by an authorized administrator of DigitalCommons@University of Nebraska - Lincoln. 


\title{
Developing Formal Reasoning through the Study of English
}

\author{
Anton E. Lawson \\ Elmer A. Kral
}

\begin{abstract}
Although hardly immune to criticism, Piaget's concept of sensorimotor, preoperational, concrete, and formal operational stages of thought has considerable face validity. In view of the accumulated Piagetian observations that critical reasoning skills develop in a generally sequential order, the finding that a substantial proportion of adolescents and adults demonstrate very little competency with formal reasoning skills ${ }^{1}$ poses a serious educational concern. The purpose of this article is to present ten practical teaching procedures to encourage students to develop formal reasoning skills. A 12th-grade English course will be used as an example.

Let us consider one by one the procedures listed in Table 1.

(1) Pretest students at the start of the year to determine their respective stages of reasoning. Use this information to assign students to groups. A number of tests have been developed during the past few years that can be used by teachers for this purpose. ${ }^{2}$ One must keep in mind, however, that a student's failure to solve the test problems does not necessarily imply that he or she is not capable of the reasoning in question. One can fail to solve problems for any number of reasons, lack of motivation and anxiety being two important ones. Therefore, the analysis of test results is helpful, but must be followed up by observations and infor-
\end{abstract}

Anton E. Lawson is associate professor, Department of Zoology, Arizona State University; Tempe, Arizona 85287. Elmer A. Kral is instructor, Department of English, Grand Island Senior High School, Grand Island, Nebraska 68801. 


\section{THE EDUCATIONAL FORUM}

mal discussions during the semester to acquire a clear picture of reasoning competence.

The grouping of students on the basis of this type of analysis has proven to be extremely helpful not only to students but also to the teacher. It facilitates teacher-to-student communication, intragroup discussion, and learning on the part of all group members. In short, it makes the teacher's job not only much easier but more effective.

Table 1

Teaching Procedures for Developing Formal Reasoning

1. Pretest students at the start of the year to determine their stage of reasoning. Use this information to group students into groups of three to five (a balance of concrete, transitional and formal thinkers in each group) to facilitate peer teaching.

2. Sequence instruction along the concrete to formal operational continuum.

3. Initiate lessons by providing students with concrete experiences which embody the reasoning that one wishes to develop.

4. Highlight, discuss, debate, and name key reasoning patterns and forms of argumentation.

5. Provide students a variety of opportunities (including written reports and essays) to employ the reasoning patterns and forms of argumentation that have been introduced.

6. Make initial assignments fairly structured and of a short duration. Gradually reduce structure to increase student autonomy and extend the length of time students must work to complete an assignment.

7. Have students write argumentative essays and gradually extend the audience they are asked to write for to provide for broader and more varied feedback on the validity of their beliefs and reasoning.

8. Provide an environment which encourages discussion and debate by continually raising questions about the literature being read such as: What do you think the author might have meant? What other possibilities exist? Why do you think so? How could you test your idea? What conclusions can be drawn?

9. Show empathy and give encouragement, especially to students who are not formal thinkers.

10. Base a substantial portion of students' grades on the quality of their reasoning yet insure that students are rewarded for improvement.

(2) Sequence instruction along the concrete to formal operational continuum. Two major variables of the subject matter of English can be analyzed and sequenced along the concrete to formal operational continuum. The first is the type of discourse students read, analyze and create. The second is the form of argumentation they read, discuss and generate in 
support of major assertions in readings, classroom discussions, speeches or essays.

Figure 1 shows a classification of major types of discourse found in literature. ${ }^{3}$ As shown, discourse is divided into three major types poetic, expressive and transactional. The writing and interpretation of poetic discourse can be regarded as requiring preoperational, concrete, or formal reasoning, depending upon the specific piece of discourse in question. Many poems, nursery rhymes and short stories can be read simply for amusement; thus, no reasoning is required. On the other hand, when one is engaged in the generation and systematic testing of hypotheses regarding the meaning of poetic discourse, formal reasoning skills are called for. Expressive writing, due to its personal and unstructured nature, seldom requires formal reasoning. Transactional discourse varies considerably in the demands it places on reasoning skills. By nature, regulative transactional discourse simply issues instructions to be followed; therefore, the learner is not necessarily required to reason. Of course, the process of developing these regulations may require a considerable amount of reasoning. Persuasive transactional discourse involves concrete or formal reasoning, depending upon the types of arguments used in the discourse. Our analysis below of forms of argumentation reveals that some arguments involve formal reasoning while others do not.

The various subcategories of informative transactional discourse have been arranged in the figure to reflect increasing levels of reasoning as one progresses from left to right. The record and report (running commentary or account of past events), like viewing or recounting what takes place in dreams, requires little or no reasoning. However, low and high level generalizations require the use of concrete reasoning skills, more so for high level generalization, as events are classified and seriated, and certain constancies are isolated from the potentially confusing mass of information in the events described. Finally, speculative and theoretical discourse requires formal reasoning as hypotheses are advanced and evidence and arguments are advanced in their support (more so for theoretical discourse).

A proper sequencing of types of discourse in the curriculum requires introducing those that require preoperational reasoning first, then those that require concrete reasoning, and finally those that require formal reasoning. Where one starts along this continuum depends largely upon the level of the students. Most assuredly, if the development of formal reasoning is a goal, then the course emphasis should be on the formal types of discourse. For example, in our experimental 


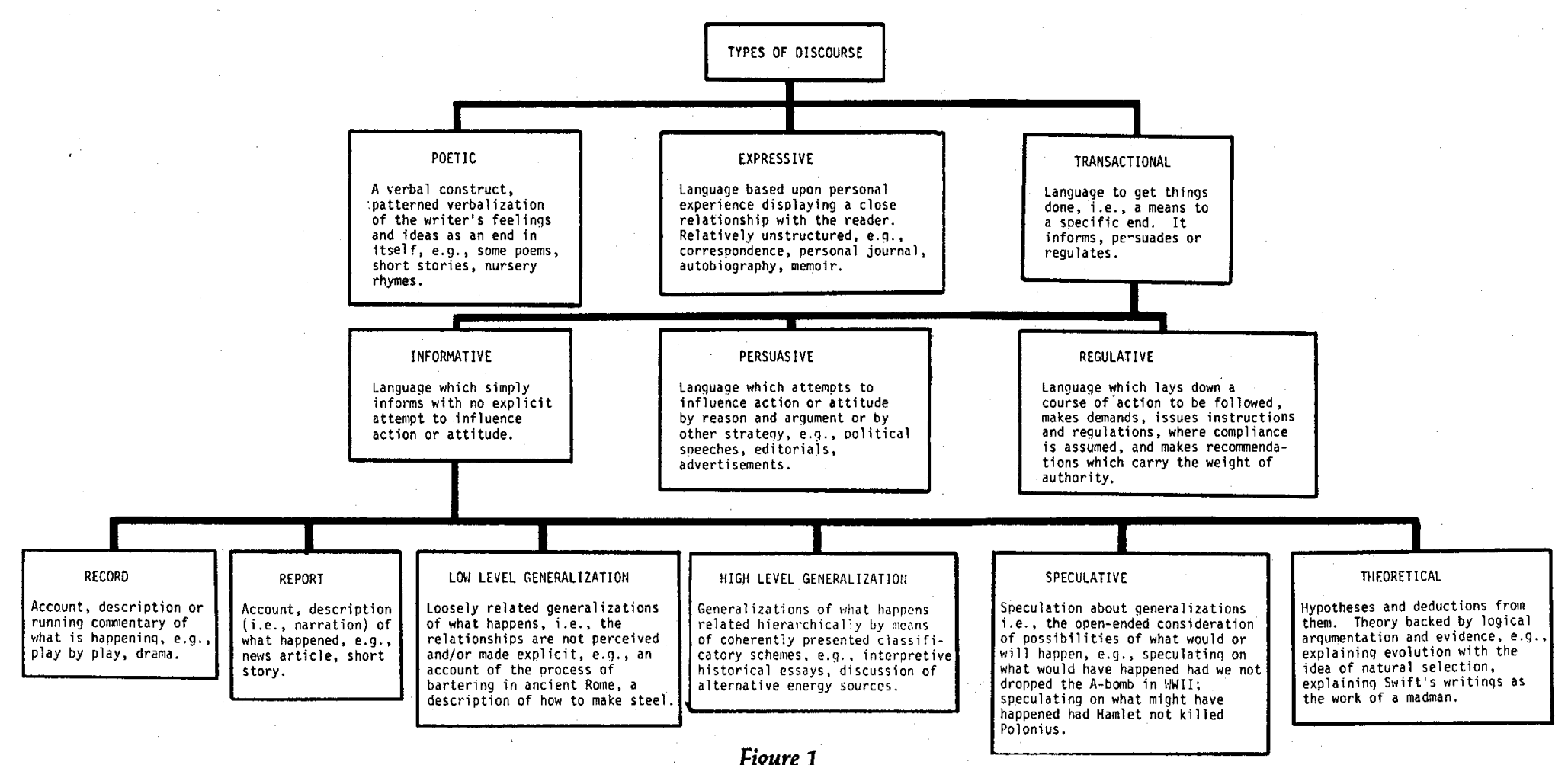

Figure 1

Types of Discourse 
course, where many students are transitional between concrete and formal levels, initial essays call for high level generalization. Speculative, theoretical, and persuasive essays are soon introduced with emphasis upon forms of argumentation that involve formal reasoning. For younger or more concrete-operational students, one should start with expressive writing or records and reports before moving toward intellectually more demanding assignments. 4

Figure 2 shows a classification scheme of the other major subject matter variable, the form of argumentation (i.e., discourse presented to support or refute an assertion about something). Various forms of argumentation are well known in textbooks of argument, critical thinking, and debate, 5 but they have not so far been analyzed from the point of view of the level of reasoning involved in their comprehension and generation.

Comprehension or generation of arguments by sign and analogy are not considered to require concrete or formal reasoning, because classsubclass or causal relationships are not involved. In contrast, arguments by example (essence and existence) are considered to require concrete operational reasoning in that class-subclass relationships are involved. Arguments of causal correlation and causal generalization are judged to involve formal reasoning, because evidence is sought to establish cause-effect or correlational relationships. Thus, arguments by sign and analogy are introduced first in the course, followed by those by example and finally, by arguments by causal correlation and causal generalization.

The introduction of forms of argumentation is done through the reading and analysis of literary works. Students read works such as Shakespeare's Hamlet, Thomas Hardy's Mayor of Casterbridge, John Know-les's A Separate Peace, William Golding's Lord of the Flies, and Jonathan Swift's Gulliver's Travels. These books have been selected primarily on the basis of the arguments they contain and the questions they raise. Students begin by reading passages that contain arguments or which raise questions that can be answered only through hypothesis generation, evidence gathering and argumentation.

Consider, for example, the sign argument used to support the assertion that the motive for Hamlet's killings was revenge. The following signs can be offered: (1) he killed Polonius because he thought Polonius was Claudius and Hamlet believed Claudius had killed his father; (2) he killed Rosencrantz and Guildenstern because they were pawns in a plot to kill him; and (3) he killed Laertes because Laertes stabbed him. In this argument three pieces of circumstantial evidence are offered in sup- 

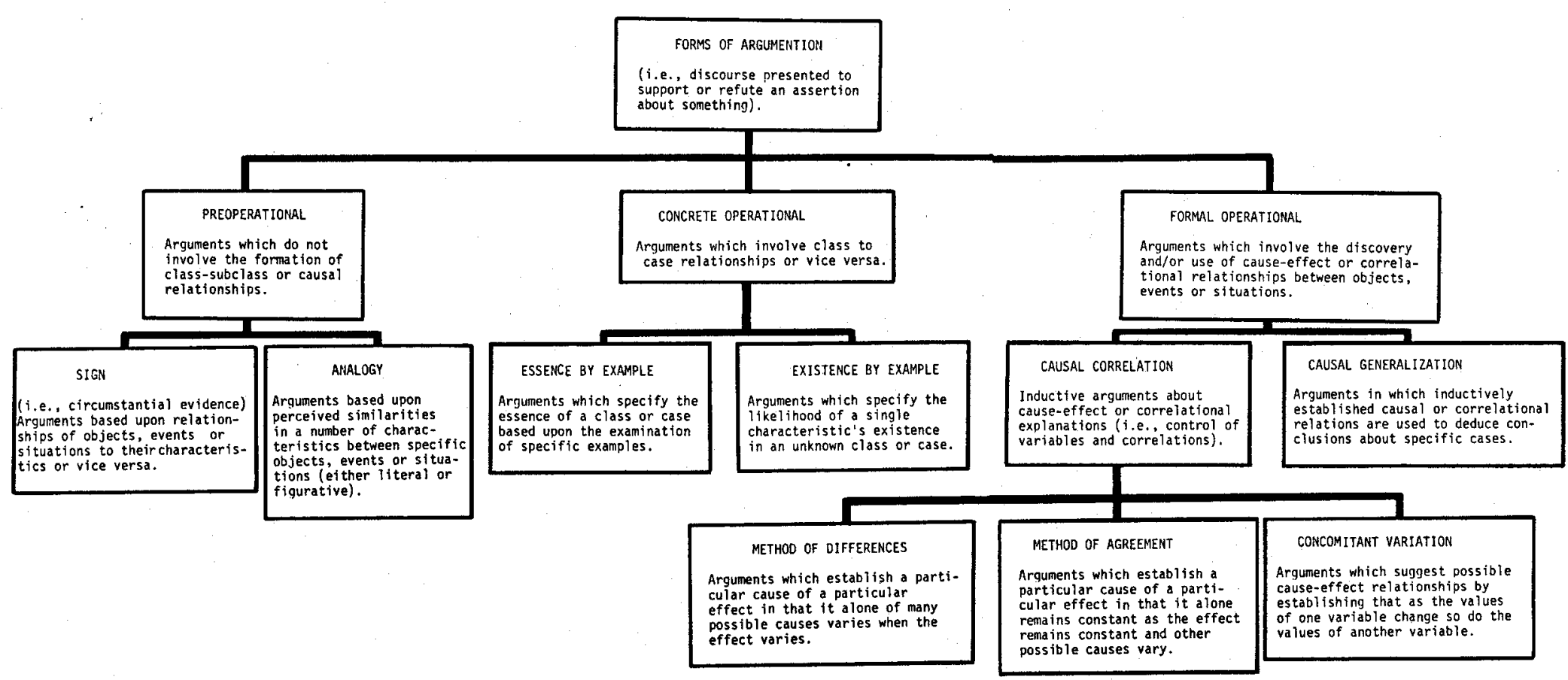

(1)

Arguments which involve the discovery

and/or use of cause-effect or correlaA
Anal relationships between objects.

Figure 2

Forms of Argumentation 
port of the assertion. A sign argument is also made when the following circumstantial evidence is offered in support of the assertion that Gene caused Finny to fall from the tree and break his leg in Knowles's $A$ Separate Peace: (1) Gene's actions at the tree during the incident; (2) Gene's anger at Finny for causing him to flunk a trigonometry test; (3) Gene's anger at Finny for making him watch Leper jump from the tree, and (4) Gene's statements that he was jealous of Finny.

The other form of argumentation that we believe does not require specific concrete or formal reasoning skills is argument by analogy. The entire satirical works of Gulliver's Travels and Lord of the Flies are arguments by analogy in which the authors present situations assumed to be analogous to the real world to enlighten the reader about characteristics of oneself and one's world. Swift drew a specific analogy in Gulliver's Travels between an egg and the interpretation of religious doctrine, and argued that it did not matter how one went about examining religious doctrine in that it did not matter which side of an egg one cracked to get at the yolk.

Arguments of existence by example and essence by example involve class to case or case to class relationships. Therefore, they have been classified at the concrete operational level. In The Mayor of Casterbridge, one can argue that the Mayor's next personal interaction will most likely result in a negative impact on his life in that eight out of ten of his previous personal interactions (e.g., selling his wife, refusing to exchange spoiled corn, jilting Lucetta) have resulted in negative impacts. Likewise, Golding argues through numerous examples offered through Lord of the Flies that defects in human nature exist. In Hamlet, the prince uses an argument of essence by example to conclude that "there is something rotten in the state of Denmark," in fact in all of human nature (corruptness is the essence of human nature), based upon the murder of his father, his mother's hasty remarrying, and the behavior of drunken palace guards.

The remaining arguments require formal reasoning, as they require the discovery and use of cause-effect, or correlational relationships. These arguments are basically of two types - inductive and deductive. Inductive arguments are termed arguments by causal correlation. There are three types of arguments by causal correlation called method of differences, method of agreement and concomitant variation. ${ }^{6}$ The methods of differences and agreement require the formal operational skill of the isolation and control of variables (in fact these are psychologically one and the same), while generating an argument of concomitant variation requires use of the formal skill known as correlational reason- 


\section{THE EDUCATIONAL FORUM}

ing. The one form of deductive argument based upon cause-effect or correlational relationships is known as causal generalization in which inductively established causal or correlational relationships are used to deduce conclusions about specific cases.

While reading $A$ Separate Peace, students are introduced to argumentation by the method of differences when attempting to answer the question: Why was Gene able to cope while Leper was not? The assertion that Gene was able to cope better than Leper because he was more assertive is supported by noting that this was the only significant way in which the boys differed. They were both the same age, both participated in the same activities, both were sensitive, both were intellectual, and both were serious students. Similarly, while reading The Mayor of Casterbridge, students are introduced to the method of agreement (process of elimination, or exclusion of irrelevant variables) in arguing that excessive drinking, bad temper, and women are not the causes of Henchard's troubles because his troubles continue even when his drinking is curtailed, when his temperament improves, and when he avoids women.

The most complex reasoning introduced in the course involves argumentation by concomitant variation, as correlations between variables are induced from specific instances within the novels. This form of argumentation seldom, if ever, is used by the characters within the novels, but is commonly used by the critical reader. For example, the critic who argues that Hamlet's hasty actions were caused by emotional trauma may cite six instances in which hasty actions were immediately preceded by emotional trauma (while ignoring two deliberate actions that were preceded by emotional trauma). Likewise, to support the assertion that fear ultimately destroys man's ability to reason logically, the critic using argument by concomitant variation would note that in Lord of the Flies, the majority of the children's decisions in the absence of fear were logical, while the majority of decisions reached when they were afraid were illogical.

The final form of argumentation, that of causal generalization, uses inductively established causal or correlational relationships as the basis for the deduction of conclusions in specific cases. For example, in The Mayor of Casterbridge, the assertion that Henchard's inability to make rational decisions causes poor interpersonal relationships allows one to deduce that Henchard's next decision regarding his corn manager will result in a poor interpersonal relationship. In Hamlet, the following deductive argument could be made to predict Hamlet's next action: emotional trauma causes Hamlet to act hastily. Hamlet has just had an 
emotional trauma (he was stabbed in the back by Laertes). Therefore, Hamlet will act hastily (he kills Claudius). Or consider this argument in Lord of the Flies: fear causes man to make irrational decisions. The boys are afraid of the beast. Therefore, the boys are likely to make an irrational decision (the boys decided to put the pig's head on the end of a stick).

(3) Initiate lessons by providing students with concrete experiences embodying the reasoning that one wishes to develop.

(4) Highlight, discuss, debate, and name key reasoning patterns and forms of argumentation.

(5) Provide students a variety of opportunities (including written reports and essays) to employ the reasoning patterns and forms of argumentation that have been introduced.

These teaching procedures form the three parts of a model of instruction called the learning cycle. The cycle, which consists of the phases of exploration, concept introduction, and concept application, is designed to encourage self-regulation and the intellectual development of students. The exploration phase involves students in initial experiences with materials. As a consequence of these explorations, students encounter new information for which they may not have the necessary knowledge to allow immediate assimilation. This may produce disequilibrium.

At the appropriate time, determined by the teacher, a way of ordering the experiences is suggested. The teacher introduces a new concept or reasoning pattern, a new way of thinking about the experiences. Such introduction often includes a new term such as tone, style, character, method of differences or concomitant variation. This phase, termed concept introduction, is analogous to Piaget's structure-building, and may promote a new state of understanding or equilibrium. In most cases, however, the concept introduction phase will not immediately allow students to coordinate mentally the new terminology and assure a way of ordering the experiences. Disequilibrium thus persists. This is why phase three, concept application, is so important. In this phase, further experiences are presented that involve the same concepts or reasoning patterns. During concept application most students are able to selfregulate and come to new understandings. These experiences serve to reinforce, refine, and enlarge the content of the ideas introduced.

Table 2 provides a list and brief description of each learning cycle in the experimental class. As an example of one learning cycle consider the way in which the reasoning involved in argumentation by the methods of differences and agreement are introduced in Learning Cycle No. 8. Exploration involves having students play the game of 
THE EDUCATIONAL FORUM

Table 2

Learning Cycles for a 12th Grade English Course Emphasizing the Development of Formal Reasoning

\begin{tabular}{|c|c|c|c|}
\hline $\begin{array}{l}\text { Learning Cycle } \\
\text { Name }\end{array}$ & $\begin{array}{c}\text { Exploration } \\
\text { Phase }\end{array}$ & $\begin{array}{c}\text { Concept } \\
\text { Introduction } \\
\text { Phase }\end{array}$ & $\begin{array}{c}\text { Concept } \\
\text { Application } \\
\text { Phase }\end{array}$ \\
\hline $\begin{array}{l}\text { 1. Generating and } \\
\text { testing hypotheses }\end{array}$ & $\begin{array}{l}\text { Candle burning } \\
\text { experiment }\end{array}$ & $\begin{array}{l}\text { Hypothesis, prediction, } \\
\text { evidence, conclusion, } \\
\text { hypothetico-deductive } \\
\text { reasoning }\end{array}$ & $\begin{array}{l}\text { Do Reasoning } \\
\text { Module } 5 \\
\text { Analyze a poem and } \\
\text { short story } \\
\text { Write a lab report }\end{array}$ \\
\hline $\begin{array}{l}\text { 2. Argument by } \\
\text { analogy }\end{array}$ & $\begin{array}{l}\text { Read Swift's essay "A } \\
\text { Modest Proposal" and } \\
\text { relevant history }\end{array}$ & $\begin{array}{l}\text { Argument by analogy, } \\
\text { assertion }\end{array}$ & $\begin{array}{l}\text { Analyze analogies in } \\
\text { other fields } \\
\text { Write one-page paper } \\
\text { using argument by } \\
\text { analogy }\end{array}$ \\
\hline 3. Character & $\begin{array}{l}\text { Read Mayor of } \\
\text { Casterbridge, Chapters } \\
1-13 \\
\text { Gather data on student } \\
\text { characteristics in class }\end{array}$ & $\begin{array}{l}\text { Characteristic, variables, } \\
\text { constants, values }\end{array}$ & $\begin{array}{l}\text { Discuss Henchard's } \\
\text { motives } \\
\text { Write a character sketch }\end{array}$ \\
\hline 4. Argument by sign & $\begin{array}{l}\text { Raise questions about } \\
\text { what happened and } \\
\text { why in The Mayor } \\
\text { Call for evidence }\end{array}$ & $\begin{array}{l}\text { Argument by sign, } \\
\text { motive, circumstantial } \\
\text { evidence }\end{array}$ & $\begin{array}{l}\text { Discover sign } \\
\text { arguments in other } \\
\text { pieces of literature } \\
\text { Write a paragraph using } \\
\text { a sign argument }\end{array}$ \\
\hline $\begin{array}{l}\text { 5. Argument by } \\
\text { example }\end{array}$ & $\begin{array}{l}\text { Read The Mayor, } \\
\text { Chapters 14-31 } \\
\text { Gather data on student } \\
\text { opinion of the book and } \\
\text { plot frequency } \\
\text { distribution }\end{array}$ & $\begin{array}{l}\text { Sample, population, } \\
\text { normal curve }\end{array}$ & $\begin{array}{l}\text { Do Reasoning Module } 1 \\
\text { Analyze arguments in } \\
\text { other literature } \\
\text { Write a three-page } \\
\text { essay on the novel }\end{array}$ \\
\hline $\begin{array}{l}\text { 6. Chance or external } \\
\text { cause }\end{array}$ & $\begin{array}{l}\text { Discuss chance events } \\
\text { in The Mayor, generate } \\
\text { hypotheses }\end{array}$ & $\begin{array}{l}\text { Chance, cause-effect, } \\
\text { probability }\end{array}$ & $\begin{array}{l}\text { Do Reasoning Module } 3 \\
\text { on probability, sample } \\
\text { brown and white beans, } \\
\text { generate tree diagrams, } \\
\text { study newspaper } \\
\text { examples and do } \\
\text { problems }\end{array}$ \\
\hline $\begin{array}{l}\text { 7. Chance or internal } \\
\text { motivation }\end{array}$ & $\begin{array}{l}\text { Read Garratt vs. Daily } \\
\text { legal case, } A \text { Separate } \\
\text { Pence, chapters 1-4 }\end{array}$ & Intent & $\begin{array}{l}\text { Debate intent of Gene } \\
\text { Analyze forms of } \\
\text { argument used in } \\
\text { debate } \\
\text { Read True, False or In } \\
\text { Between pps. 1-24 }\end{array}$ \\
\hline $\begin{array}{l}\text { 8. Argument by } \\
\text { method of } \\
\text { agreement or } \\
\text { differences }\end{array}$ & $\begin{array}{l}\text { Play Mastermind, analyze } \\
\text { reasoning strategies }\end{array}$ & $\begin{array}{l}\text { Independent and } \\
\text { dependent variable, } \\
\text { controlled experiment, } \\
\text { method of agreement or } \\
\text { differences }\end{array}$ & $\begin{array}{l}\text { Do Reasoning Module } \\
4 \text { experiments on } \\
\text { candle burning and } \\
\text { problems } \\
\text { Discuss arguments in } \\
\text { The Mayor and } A \\
\text { Separate Pente } \\
\text { Write one-page } \\
\text { paragraph on } A \text { Separate } \\
\text { Peace }\end{array}$ \\
\hline
\end{tabular}


REASONING THROUGH ENGLISH

\begin{tabular}{|c|c|c|c|c|}
\hline & $\begin{array}{l}\text { Learning Cycle } \\
\text { Name }\end{array}$ & $\begin{array}{l}\text { Exploration } \\
\text { Phase }\end{array}$ & $\begin{array}{c}\text { Concept } \\
\text { Introduction } \\
\text { Phase }\end{array}$ & $\begin{array}{l}\text { Concept } \\
\text { Application } \\
\text { Phase }\end{array}$ \\
\hline 9. & $\begin{array}{l}\text { Argument by } \\
\text { concomitant } \\
\text { variation }\end{array}$ & $\begin{array}{l}\text { Graph data gathered in } \\
\text { Learning Cycle } 3\end{array}$ & $\begin{array}{l}\text { Correlation, median, } \\
\text { contingency table, } \\
\text { argument by } \\
\text { concomitant variation }\end{array}$ & $\begin{array}{l}\text { Do Reasoning Module } \\
2 \\
\text { Discuss correlations in } \\
\text { A Separate Peace } \\
\text { Write three-page essay } \\
\text { on } A \text { Separate Peace }\end{array}$ \\
\hline 10. & $\begin{array}{l}\text { Argument by causal } \\
\text { generalization }\end{array}$ & $\begin{array}{l}\text { Investigate examples } \\
\text { from editorials } \\
\text { Read Lond of the Flies }\end{array}$ & $\begin{array}{l}\text { Argument by causal } \\
\text { generalization, } \\
\text { syllogism, major } \\
\text { premise, minor premise }\end{array}$ & $\begin{array}{l}\text { Analyze arguments } \\
\text { used in Lord of the Flies } \\
\text { Write editorial using } \\
\text { argument by causal } \\
\text { generalization and } \\
\text { others }\end{array}$ \\
\hline 11. & $\begin{array}{l}\text { Combinations, } \\
\text { permutations, and } \\
\text { mystery writing }\end{array}$ & $\begin{array}{l}\text { Play Clue } \\
\text { Do combinatorial } \\
\text { problems }\end{array}$ & $\begin{array}{l}\text { Combinations, } \\
\text { permutations, principle } \\
\text { of counting }\end{array}$ & $\begin{array}{l}\text { Write an "unfinished" } \\
\text { mystery story }\end{array}$ \\
\hline 12. & $\begin{array}{l}\text { Critical analysis of } \\
\text { Hamlet }\end{array}$ & $\begin{array}{l}\text { Read play and view } \\
\text { films }\end{array}$ & $\begin{array}{l}\text { Reintroduce forms of } \\
\text { argument and } \\
\text { hypothetico-deductive } \\
\text { reasoning }\end{array}$ & $\begin{array}{l}\text { Write a position paper } \\
\text { on Hamlet using various } \\
\text { forms of argument }\end{array}$ \\
\hline 13. & $\begin{array}{l}\text { Analysis and } \\
\text { creation of poetry }\end{array}$ & $\begin{array}{l}\text { Read poems and } \\
\text { generate and test } \\
\text { hypotheses regarding } \\
\text { meaning }\end{array}$ & $\begin{array}{l}\text { Metaphor, connotation, } \\
\text { tone, meter, etc. }\end{array}$ & $\begin{array}{l}\text { Analyze and write } \\
\text { poetry }\end{array}$ \\
\hline 14. & $\begin{array}{l}\text { Persuasive speech } \\
\text { writing }\end{array}$ & $\begin{array}{l}\text { Read and listen to well } \\
\text { known speeches }\end{array}$ & $\begin{array}{l}\text { Style: parallelism, } \\
\text { anaphora, alliteration, } \\
\text { etc. }{ }^{8}\end{array}$ & $\begin{array}{l}\text { Write and deliver a } \\
\text { persuasive speech }\end{array}$ \\
\hline 15. & $\begin{array}{l}\text { Position or research } \\
\text { paper }\end{array}$ & Read sources & Invent thesis & $\begin{array}{l}\text { Gather evidence, } \\
\text { outline, write, edit, } \\
\text { type and proofread }\end{array}$ \\
\hline 16. & $\begin{array}{l}\text { Problem-solving } \\
\text { strategies No. } 1\end{array}$ & $\begin{array}{l}\text { Attempt solution of } \\
\text { reasoning puzzles }\end{array}$ & Truth tables & $\begin{array}{l}\text { Apply tables to } \\
\text { additional puzzles }\end{array}$ \\
\hline 17. & $\begin{array}{l}\text { Problem-solving } \\
\text { strategies No. } 2\end{array}$ & $\begin{array}{l}\text { Attempt solution of } \\
\text { reasoning puzzles }\end{array}$ & Heuristics & $\begin{array}{l}\text { Apply heuristics to } \\
\text { additional puzzles }\end{array}$ \\
\hline 18. & $\begin{array}{l}\text { Critical analysis of } \\
\text { Gulliver's Travels }\end{array}$ & $\begin{array}{l}\text { Examine political } \\
\text { cartoons. } \\
\text { Read Gulliver's Travels }\end{array}$ & $\begin{array}{l}\text { Generate and test } \\
\text { hypotheses regarding } \\
\text { author's meaning }\end{array}$ & $\begin{array}{l}\text { Reflect on educational } \\
\text { experience and make a } \\
\text { statement in the form } \\
\text { of a cartoon, satire, or } \\
\text { letter to the editor }\end{array}$ \\
\hline
\end{tabular}

Mastermind. This game requires students to guess the correct color and sequence of four pegs hidden behind a screen by generating hypotheses that are tested through feedback given by the person who hid the pegs. A number of reasoning patterns may be employed in the course of playing the game but a most successful method of discovering the solution utilizes the methods of differences and agreement, essentially the control of variables strategy in which only one peg color or position is varied at a time. 


\section{THE EDUCATIONAL FORUM}

8. Edward P. J. Corbett, Classical Rhetoric for the Modern Student (New York: Oxford University Press, 1965).

9. Anton E. Lawson, Theodore W. Munch, and Bill Tillery, Exploration in Life Science (Tempe, Ariz.: Arizona Board of Regents, 1978).

10. William H. Leonard, "Using the Extended Discretion Approach to Biology Laboratory Investigations," American Biology Teacher 42 (October 1980): 338-348.

11. Britton et al., Development of Writing.

12. Moffet, Teaching and Universe. 